\title{
BRPKM
}

Buletin Riset Psikologi dan Kesehatan Mental

http://e-journal.unair.ac.id/index.php/BRPKM

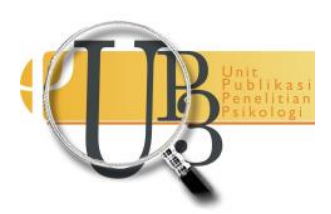

ARTIKEL PENELITIAN

\section{Pengaruh Keterlibatan Ayah Terhadap Kecenderungan Perilaku Kenakalan Remaja}

\section{ADINDALIA YUNIAR BRILLYANA}

Departemen Psikologi Psikologi Pendidikan dan Perkembangan, Fakultas Psikologi Universitas Airlangga

\begin{abstract}
ABSTRAK
Penelitian ini bertujuan untuk mengetahui pengaruh keterlibatan ayah terhadap kecenderungan perilaku kenakalan remaja di Surabaya. Kenakalan remaja adalah suatu perbuatan yang dilakukan oleh remaja dengan mengabaikan nilai-nilai sosial yang berlaku di dalam masyarakat. Keterlibatan ayah merupakan peran yang dimainkan seseorang yang berkaitan dengan anak, bagian dari sistem keluarga, komunitas, dan budaya. Jumlah sampel dalam penelitian ini sebanyak 201 remaja di Surabaya. Penelitian ini menggunakan pendekatan kuantitatif dengan metode survey. Pengumpulan data menggunakan alat ukur skala kecenderungan perilaku kenakalan remaja dan skala keterlibatan ayah. Hasil Analisis data menunjukkan bahwa keterlibatan ayah memiliki pengaruh terhadap kecenderungan perilaku kenakalan remaja di Surabaya. Hal tersebut dapat dilihat dari taraf signifikansi kurang dari 0,05 yaitu sebesar 0,000 . Keterlibatan ayah dan kecenderungan perilaku kenakalan remaja di Surabaya sebesar $12 \%(\mathrm{R} 2=0,120)$.
\end{abstract}

Kata kunci: keterlibatan ayah, kenakalan remaja

\section{ABSTRACT}

This study aims to see the effect of father interaction on juvenile delinquency behavior in Surabaya. Juvenile delinquency is an act committed by adolescents by ignoring the social values prevailing in society. The involvement of the father is the role played by someone related to the child, part of the family system, community, and culture.The number of samples in this study were 201 teenagers in Surabaya. This research uses a quantitative approach with a survey method. Data collection used a measuring tool for juvenile delinquency behavior scale and the father's interaction scale.The results of the data analysis show that the father's interaction has an influence on the tendency of juvenile delinquency behavior in Surabaya. This can be seen from the significance level of less than 0.05, which is equal to 0.000. Father involvement and juvenile delinquency behavior in Surabaya was 12\% (R2 = $0.120)$.

Keywords: father's involvement, juvenile delinquency

Buletin Penelitian Psikologi dan Kesehatan Mental (BRPKM), 2021, Vol. 1(1), 379-386

*Alamat korespondensi: Fakultas Psikologi Universitas Airlangga, Kampus B Universitas Airlangga Jalan

Airlangga 4-6 Surabaya 60286. Surel: adindalia.yuniar.brillyana-2016@psikologi.unair.ac.id 
Naskah ini merupakan naskah dengan akses terbuka dibawah ketentuan the Creative Common Attribution License (CC-BY-4.0) (http://creativecommons.org/licenses/by/4.0), sehingga penggunaan, distribusi, reproduksi dalam media apapun atas artikel ini tidak dibatasi, selama sumber aslinya disitir dengan baik.

\section{P E N D A H U L U A N}

Masa remaja ialah jembatan dari masa anak- anak ke remaja dengan pergantian yang mengacu pada pertumbuhan kognitif, biologis, serta sosioemosional di mana remajacenderung terbuka menimpa halhal yang bertabiat individu pada sahabat sebayanya. Remaja disini lebih tergantung pada sahabat sebayanya daripada orang tua buat penuhi kebutuhan ketenangan hati, kebersamaan terhadap sahabatnya, serta pula intimasi (Santrock, 2011)

Remaja yang terus menjadi matang hendak cenderung membebaskan diri dari orang tua, remajayang merasa dirinya telah matang hendak mengawali pencarian jati dirinya tanpa dorongan dari orang lain selain orang tua. Apabila remaja sukses menanggulangi konflik identitasnya hingga remaja hendak menerima bukti diri yang cocok dengan dirinya, sebaliknya untuk remaja yang tidak sanggup menanggulangi konflik identitasnya, remaja yang hendak cenderung hadapi kebimbangan bukti diri. Kebimbangan idetitas ini akan membuat remaja menarik diri serta mengisolasi diri dari sahabat sebaya serta keluarga. Remaja yang sedang hadapi kebimbangan bukti diri hendak menuju pada bukti diri yang negatif sehingga mudah untuk ikut serta dalam hal- hal yang melanggar ketentuan ataupun norma sosial yang terdapat (Santrock, 2011)

Contohnya seperti kenakalan remaja, Di Jawa Timur sendiri, angka kriminalitas remaja cukup mengkhawatirkan. Fenomena kenakalan remaja selalu eksis setiap tahunnya di Negeri ini. Kenakalan remaja kini sudah menjadi salah satu masalah yang serius dalam kehidupan bermasyarakat contohnya pada penggunaan NAPZA di Jawa Timur dalam kurun waktu 3 tahun mengalami peningkatan yang signifikan (Prasetyo, 2019). Bentuk dari kenakalan remaja yang lainnya adalah tawuran, seks bebas, merokok, pemakaian obat-obatan terlarang, pencurian, dan pemerkosaan. Dengan begitu pengertiannya secara etimologis adalah anak jahat/kejahatan anak. Dilihat dari subjek/pelakunya, maka menjadi kenakalan remaja yang berarti penjahat anak atau anak jahat (Sudarsono, 2010)

Kecenderungan perilaku kenakalan remaja dapat diprediksi menggunakan teori dari Icek Ajzen yaitu Theory of Planned Behaviour (TPB). Menurut Beck (1991) mengatakan bahwa factor sentral dari theory of planned behaviour adalah intensi seseorang untuk melakukan perilaku tertentu. Teori ini menjelaskan bahwa perilaku seseorang yang tampak ditentukan oleh intensi yang mendasari perilaku tersebut, yang mana intensi adalah menunjukkan seberapa besar keinginan seseorang untuk mewujudkan suatu perilaku (Yogatama, 2013). Terdapat tiga faktor penentu intensi dalam berperilaku yaitu, attitude toward behavior, subjective norm, dan perceived behavioral control (Machrus, 2010).

Mayoritas para remaja sekarang lebih tertutup dengan orang tuanya sebelum ditanya terlebih dahulu dan menimbulkan reaksi yang menunjukkan rasa kepercayaan, penerimaan, dan kualitas yang yang tinggi (Keijsers, 2010). Padahal peran orang tua memainkan peran yang penting dalam tumbuh kembang remaja (Collins, 2004), Kurangnya keterlibatan dan pembinaan dari orang tua akan menyebabkan perilaku remaja yang menyimpang seperti melanggar norma-norma yang telah berlaku dalam masyarakat. Begitu juga sebaliknya jika remaja terlalu dikekang maka remaja akan merasa tertekan dan bisa melakukan tindakan yang tidak terduga seperti tindakan kriminal yang menyimpang 
hukum. Pembentukan watak dan kepribadian remaja sangat dipengaruhi oleh keluarganya (Kartono, 2007).

Penelitian yang dilakukan oleh Ball (2007) menemukan adanya Disfungsi keterlibatan ayah dalam pengasuhan dapat menjadi faktor kenakalan remaja, sebaliknya ayah yang terlibat dalam pengasuhan dapat menurunkan kenakalan pada remaja. Hasil dari ketidakhadiran seorang ayah menunjukkan bahwa remaja akan cenderung tidak berhasil dalam perkembangannya (McLanahan, 1994).

Ayah sebagai pendamping remaja mempunyai kemampuan untuk mendampingi remajasupaya mereka tidak tercebur ke dalam pergaulan yang membawanya ke dalam kenakalan remajaserta aksi yang lain yang bisa merugikan diri sendiri. Ayah sebagai konselor atau penasehat, kedudukan ayah sangat berarti dalam mendampingi remaja, kala mengalami masa-masa susah dalam mengambil keputusan untuk dirinya. Ayah sebagai komunikator, dimana ikatan yang baik antara orang tua serta remaja hendak sangat menolong dalam membina mereka. Apabila antara ikatan antara ayah dengan remaja terjalin, hingga satu sama lain hendak terbuka serta silih mempercayai. Bagaikan sahabat ataupun teman, dalam mengalami remaja yang sudah merambah akhir balig, dengan demikian seorang ayah butuh kesabaran serta pengertian pada remaja atau anak mereka (O'Brien, 2009).

Maka dapat disimpulkan bahwa peran ayah dalam keluarga selain sebagai seorang pemimpin dalam keluarga, ayah juga berperan sebagai penyedia kebutuhan remaja, memberikan perhatian, merawat, dan mendukung remaja untuk mencapai impiannya. Sehingga peneliti tertarik untuk mencari tahu pengaruh antara keterlibatan ayah dan kecenderungan perilaku kenakalan remaja di Surabaya.

\section{Partisipan}

\section{E T O D E}

Penelitian ini dilakukan di Surabaya pada remaja usia sekitar 18-22 tahun yang berjumlah 201 orang. Partisipan dalam penelitian ini adalah remaja yang berada pada usia 18-22 tahun dan tinggal satu rumah dengan ayah. Teknik pengambilan partisipan yang digunakan dalam penelitian ini adalah probability sampling dengan teknik purposive sampling.

Peneliti menggunakan cara dalam pengumpulan data yaitu meminta partisipan untuk mengisi pernyataan-pernyataan yang sudah disediakan dengan kategori jawaban yang tersedia berdasarkan keadaan dan kondisi partisipan pada saat itu. Pengisian kuesioner dilakukan secara online dengan menggunakan google form.

\section{Pengukuran}

\section{Alat Ukur Kecenderungan Kenakalan Remaja}

Alat ukur Kecenderungan Kenakalan Remaja berjumlah 31 aitem dengan aitem yang telah di adaptasi oleh Aroma (2012) dari Adjzen (1975) Alat ukur yang disusun mempunyai 4 indikator yaitu Target, Action, Context, dan Time untuk mengukur tingkat kecenderungan kenakalan remaja. dengan koefisien reliabilitas yang cukup baik $(\alpha=.665)$. 
Tabel 1. Blueprint Skala Kecenderungan Kenakalan Remaja

\begin{tabular}{|c|c|c|c|c|}
\hline \multirow{2}{*}{ Indikator } & \multicolumn{2}{|c|}{ Aitem } & \multirow{2}{*}{ Jumlah } & \multirow{2}{*}{ Persen } \\
\hline & Favorable & Unfavorable & & \\
\hline $\begin{array}{c}\text { Target } \\
\begin{array}{c}\text { Pendapat atau sikap yang mengarap pada perilaku } \\
\text { kenakalan remaja }\end{array}\end{array}$ & $1,11,16,20$ & $5,9,18,24$ & 8 & $26 \%$ \\
\hline $\begin{array}{c}\text { Action } \\
\text { Perilaku yang Mengarah pada Kenakalan Remaja }\end{array}$ & $2,10,15,19$ & $6,22,25,27$ & 8 & $26 \%$ \\
\hline $\begin{array}{c}\text { Context } \\
\text { Lingkungan yang memicu terjadinnya perilaku } \\
\text { kenakalan remaja }\end{array}$ & $3,12,17,21$ & $7,23,28,31$ & 8 & $26 \%$ \\
\hline $\begin{array}{c}\text { Time } \\
\text { Waktu tertentu yang memicu terjadinya perilaku } \\
\text { kenakalan remaja }\end{array}$ & $4,13,30$ & $8,14,26,29$ & 7 & $22 \%$ \\
\hline & Jumlah & & 31 & $100 \%$ \\
\hline
\end{tabular}

\section{Alat Ukur Persepsi Keterlibatan Ayah dalam Pengasuhan}

Alat ukur Persepsi Keterlibatan Ayah dalam Pengasuhan berjumlah 44 aitem dengan aitem favorable dan unfavorable yang diadaptasi oleh Damayanti (2015) dari Lamb (2010) yang digunakan kembali oleh Puspitorini (2016) pada penelitiannya. Alat ukur disusun berdasarkan dimensi keterlibatan ayah dalam pengasuhan menurut Lamb (2010) yaitu engagement, accessibility, responsibility untuk mengukur tingkat keterlibatan ayah dalam pengasuhan yang dilihat dari persepsi remaja.

Perolehan skor total keterlibatan ayah dalam pengasuhan didapat dari alat ukur yang merupakan selfreport. Semakin tinggi skor total yang diperoleh, maka semakin tinggi pula tingkat keterlibatan ayah dalam pengasuhan. Sebaliknya semakin rendah skor total yang diperoleh, maka semakin rendah pula keterlibatan ayah dalam pengasuhan. dengan koefisien reliabilitas yang cukup baik $(\alpha=.852)$.

Tabel 2. Blueprint Skala Persepsi Keterlibatan Ayah dalam Pengasuhan

\begin{tabular}{lcrc}
\hline \multicolumn{1}{c}{ Indikator } & \multicolumn{2}{c}{ Aitem } & Jumlah \\
& Favorable & Unfavorable & \\
Engagement & $1,7,12,22,23,27,33,37,39,44$ & $6,10,16,20,24,28,29,36,38,43$ & 20 \\
& & & \\
Accessibility & $2,8,11,17,31$ & $5,15,21,34,42$ & 10 \\
Responsibility & $3,9,13,18,26,35,41$ & $4,14,19,25,30,32,40$ & 14 \\
\hline & Jumlah & & 44 \\
\hline
\end{tabular}

\section{Analisis Data}

Penelitian ini memiliki tujuan untuk menguji hipotesis mengenai pengaruh variabel $\mathrm{X}$ yaitu keterlibatan ayah terhadap variabel Y yaitu kecenderungan perilaku kenakalan remaja di surabaya. Hasil yang didapat adalah ada atau tidaknya pengaruh keterlibatan ayah terhadap kecenderungan perilaku 
kenakalan remaja di surabaya. Data penelitian akan dianalisis dengan menggunakan menggunakan bantuan SPSS 25.0 for Macbook. Teknik analisis data yang digunakan dalam penelitian ini adalah analisis regresi sederhana.

\section{HAS I L P E N EL I T IA N}

Statistik deskriptif dapat diketahui bahwa jumlah total subjek sebanyak 201 orang. Variabel keterlibatan ayah memiliki nilai tertinggi sebesar 202, nilai terendah sebesar 127 dengan rentang 75. Sedangkan pada variabel kenakalan remaja memiliki nilai tertinggi sebesar 113, sedangkan nilai terendah sebesar 75, serta dengan rentang sebesar 38. Variabel keterlibatan ayah memiliki nilai ratarata yang diperoleh yaitu sebesar 148.61 dengan standar deviasi sebesar 15,051. Sedangkan pada variabel kenakalan remaja memiliki nilai rata-rata yang diperoleh yaitu sebesar 96.55. Sedangkan pada standar deviasi memiliki nilai sebesar 8.871.

Berdasarkan hasil analisis data, diperoleh koefisien korelasi sebesar -0,347 dengan signifikansi sebesar $0,000<0,05$ yang berarti semakin tinggi keterlibatan ayah maka semakin rendah kecederungan perilaku kenakalan remaja begitu juga sebaliknya.

Lalu dalam uji regresi yang dilakukan oleh peneliti ditemukan $\mathrm{R}$ square sebesar 0,120 yang berarti keterlibatan ayah mempunyai pengaruh sebesar 12\% terhadap kecenderungan perilaku kenakalan remaja yang berarti $88 \%$ dipengaruhi oleh faktor diluaar keterlibatan ayah, serta signifikansi sebesar $0.00<0,05$ yang berarti keterlibatan ayah mempunyai pengaruh yang signifikan terhadap kecenderungan perilaku kenakalan remaja.

Uji F ataupun uji simultan dicoba untuk mengenali apakah variabel keterlibatan ayah mempengaruhi kenakalan remaja secara signifikan. Bisa dilihat pada tabel di atas, jika nilai F regression sebesar 1944. 464 dan nilai signifikasi sebesar 0, 000\&lt; 0, 05 yang menunjukkan jika variabel prediktor dalam riset ini ialah keterlibatan ayah bisa dikatakan layak untuk memprediksi variabel kenakalan remaja. Hal ini menunjukkan jika terdapat pengaruh keterlibatan ayah yang signifikan terhadap kenakalan remaja.

Bersumber pada informasi dari tabel yang terdapat di atas, diketahui jika persamaan garis linear antara variabel independen ialah keterlibatan ayah dengan variabel dependen yakni kenakalan remaja merupakan Penggambaran berlandaskan informasi yang terdapat di atas yakni apabila tidak terdapat sama sekali keterlibatan ayah hingga nilai konsistensi pada variabel kenakalan remaja sebesar 126. 837. Apabila ditinjau dari koefisien regresi keterlibatan ayah ditemukan -,347 yang berarti tiap akumulasi $1 \%$ tingkatan keterlibatan ayah sehingga kenakalan remaja seorang akan menurun sebesar 0,207. Ada pula nilai t sebesar 21.401 dan nilai Sig. 0,00<0,05 yang menampilkan jika ada pengaruh keterlibatan ayah serta kenakalan remaja di Surabaya.

\section{I S K U S I}

Besar pengaruh keterlibatan ayah terhadap kenakalan remaja yaitu 12\%, yang artinya 88\% lainnya dipengaruhi oleh faktor diluar keterlibatan ayah. Maka hal tersebut sesuai dengan hipotesis awal dimana Ha diterima, sedangkan Ho ditolak.

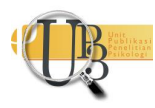


Hal ini sejalan dengan penelitian yang dilakukan oleh Horn dalam Eastin (2003) yang menemukan bahwa individu yang tumbuh dan berkembang tanpa sosok ayah banyak mengalami banyak masalah dalam hidupnya. Lalu dalam penelitian Eastin (2003) yang menemukan bahwa kenakalan yang dilakukan oleh remaja kebanyakan adalah individu yang dibesarkan tanpa keterlibatan ayah.

Pernyataan tersebut didukung penelitian lain oleh Simmons (2018) yang mengatakan bahwa tidak adanya keterlibatan ayah berpengaruh besar terhadap kenakalan remaja, meskipun terkadang kehadiran ayah juga tidak selalu positif, karena dalam penemuannya ayah yang mendidik anaknya dengan kekerasan berdampak lebih besar terhadap kenakalan remaja daripada tidak adanya keterlibatan seoarang ayah.

Pada penelitian yang dilakukan oleh Flouri (2002) ditemukan bahwa rendahnya keterlibatan ayah, rendahnya IQ, serta kriminalitas yang dilakukan oleh orang tua berpengaruh pada kenakalan remaja yang berujung pada kriminalitas, serta keunikan yang ditemukan dalam penelitian ini adalah laki-laki remaja yang berumur 16 tahun melakukan kriminalitas 3 kali lebih tinggi dari perempuan. Dalam penelitian ini menggaris bawahi bahwa keterlibatan ayah pada masa kecil sangat berpengaruh dalam perkembangannya saat remaja serta ditemukan faktor yang sangat signifikant adalah besarnya jumlah keluarga inti serta rendahnya motivasi akademik yang dimiliki oleh individu.

\section{S I M P U L A N}

Berdasarkan hasil penelitian dapat disimpulkan bahwa terdapat hubungan yang negatif antara keterlibatan ayah dan kecerungan kenakalan remaja, yang berarti semakin tinggi keterlibatan ayah maka akan semakin rendah kenakalan remaja begitu juga sebaliknya. Serta terdapat pengaruh antara keterlibatan ayah dalam pengasuhan anak terhadap kecenderungan kenakalan remaja.

\section{U C A P A N T ERIMAKASIH}

Alhamdulillah, puji syukur kehadirat Allah SWT sebab atas berkat rahmat serta hidayahnya, penulis diberi kemudahan serta kelancaran dalam menuntaskan skripsi dengan judul "Pengaruh Keterlibatan Ayah Terhadap Kecenderungan Sikap Kenakalan Remaja" bagaikan salah satu prasyarat buat mendapatkan gelar Sarjana Psikologi Universitas Airlangga Surabaya. Penulis menyadari kalau skripsi ini tidak akan tuntas tanpa dorongan serta sokongan dari banyak pihak yang ikut andil dalam proses pengerjaannya.

\section{DEKLARASI POTENSI TERJADINYAKONFLIK KEPENTINGAN}

Adindalia Yuniar Brillyana tidak bekerja, menjadi konsultan, memiliki saham, atau menerima dana dari perusahaan atau organisasi manapun yang mungkin akan mengambil untung dari diterbitkannya naskah ini

\section{P US TAKA ACUAN}

Ajzen, I. \&. (1975). A Bayesian analysis of attribution processes. Psychological bulletin, 261. 
Aroma, I. S. (2012). Hubungan antara tingkat kontrol diri dengan kecenderungan perilaku kenakalan remaja. Jurnal Psikologi Pendidikan dan Perkembangan, 1-6.

Ball J Moselle, K. \&. (2007). Father's involvement as a determinant of child health. Father Involvement Research Alliance.

Beck, L. \&. (1991). Predicting dishonest actions using the theory of planned behavior. . Journal of research in personality, 285-301.

Collins, W. A. (2004). Parent-adolescent relationships and influences. Handbook of adolescent psychology, 331-362.

Damayanti, T. S. (2015). PENYULUHAN TENTANG PENGASUHAN ANAK DI DESA DAMPIT KEC. CICALENGKA. Prosiding SNaPP: Kesehatan , 395-400.

Eastin, J. F. (2003). Impact of absent father-figures on male subjects and the correlation to juvenile delinquency: Findings and implications (Doctoral dissertation, University of North Texas).

Flouri, E. \&. (2002). Life satisfaction in teenage boys: The moderating role of father involvement and bullying. Aggressive Behavior: Official Journal of the International Society for Research on Aggression, 126-133.

Kartono. (2007). Psikologi Anak. Bandung, Jawa Barat, Indonesia: CV Mandar Maju.

Keijsers, L. B. (2010). Reciprocal effects between parental solicitation, parental control, adolescent disclosure, and adolescent delinquency. Journal of Research on Adolescence, 88-113.

Lamb, M. E. (2010). The Role of The Father In Child Development (5th Edition ed.). New Jersey, US: John Wiley \& Sons, Inc.

Machrus, H. \&. (2010). Behavioral Measurement based on Theory of Planned Behaviour. . Insan Media Psikologi, 64-72.

McLanahan, S. \&. (1994). Growing Up with a Single Parent. What Hurts, What Helps. Garden Street, Cambridge, MA 02138.: Harvard University Press.

O'Brien, M. (2009). Fathers, parental leave policies, and infant quality of life: International perspectives and policy impact. The Annals of the American Academy of Political and Social Science, 190-213.

Prasetyo, I. J. (2019). Patterns of Therapeutic Communication in Rehabilitation Institution for the Narcotics Users in East Java, Indonesia. Journal of Drug and Alcohol Research, 1-8.

Puspitorini, D. A. (2016). Hubungan Antara Persepsi Keterlibatan Ayah Dalam Pengasuhan Dengan Perilaku Kenakalan Remaja (Juvenile Delinquency) Pada Laki-Laki . Doctoral Dissertation, Universitas Airlangga.

Santrock, J. W. (2011). Life Span Development (13th ed.). (N. I. Sallama, Ed., \& B. Wisdyasinta, Trans.) . New York, America, USA: McGraw Hill.

Simmons, C. S. ( 2018). The differential influence of absent and harsh fathers on juvenile delinquency. Journal of adolescence, 9-17.

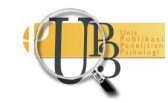


Sudarsono. (2010). Kenakalan Remaja. Prevensi, Rehabilitasi, dan Resosialisasi. Jakarta, DKI Jakarta, Indonesia: PT Rineka Cipta.

Yogatama, L. A. (2013). Analisis pengaruh attitude, subjective norm, dan perceived behavior control terhadap intensi penggunaan helm saat mengendarai motor pada remaja dan dewasa muda di Jakarta Selatan. Prosiding PESAT, 5. 